Illinois State University

ISU ReD: Research and eData

Faculty Publications - Finance, Insurance, and

Law

Finance, Insurance, and Law

2009

\title{
Year-end and Quarter-end Effects in the Term Structure of Sterling Repo and Eurepo Rates
}

\author{
Mark D. Griffiths \\ Miami University - Oxford \\ Vladimir Kotomin \\ Illinois State University, vkotomi@ilstu.edu \\ Drew B. Winters \\ Texas Tech University
}

Follow this and additional works at: https://ir.library.illinoisstate.edu/fpfil

Part of the Finance and Financial Management Commons

\section{Recommended Citation}

Griffiths, Mark D.; Kotomin, Vladimir; and Winters, Drew B., "Year-end and Quarter-end Effects in the Term Structure of Sterling Repo and Eurepo Rates" (2009). Faculty Publications - Finance, Insurance, and Law. 14.

https://ir.library.illinoisstate.edu/fpfil/14

This Article is brought to you for free and open access by the Finance, Insurance, and Law at ISU ReD: Research and eData. It has been accepted for inclusion in Faculty Publications - Finance, Insurance, and Law by an authorized administrator of ISU ReD: Research and eData. For more information, please contact ISUReD@ilstu.edu. 


\title{
Year-end and quarter-end effects in the term structure of sterling repo and Eurepo rates
}

\author{
Mark D. Griffiths \\ Jack Anderson Professor of Finance, Miami University, United States \\ Vladimir Kotomin \\ University of Wisconsin-Eau Claire \\ Drew B. Winters \\ Rawls Professor of Finance, Texas Tech University, United States
}

\begin{abstract}
Griffiths and Winters (1997) find a year-end preferred habitat for liquidity for US repo rates, and, later, Griffiths and Winters (2005) find a similar preferred habitat for US money market instruments. Kotomin et al. (2008) document the preferred habitat in LIBOR for the major world currencies, excluding the British pound. We examine the robustness of these results using pound sterling and euro repo rates and find a year-end preferred habitat for liquidity in the euro repo rates. The British interest rates continue to behave differently, and we provide a possible explanation as to why this occurs.
\end{abstract}

J.E.L. Classification Codes: G14, G15, G19

Key words: repos, preferred habitat, term structure 


\section{Year-end and quarter-end effects in the term structure of sterling repo and Eurepo rates}

\section{Introduction}

Standard explanations for the term structure of interest rates include (1) expectations theory, (2) liquidity preference theory, and (3) market segmentation theory with its corollary of preferred habitats. Modigliani and Sutch (1966) develop the preferred habitat theory to explain the twists in the term structure of interest rates observed during the Kennedy Administration. Later, Roll (1970, p. 38) states that “(p)references for certain maturities occur because fixed-payment securities are used as hedges against the payment streams of assets or liabilities that must be held in the course of business but which entail risk of interest rate fluctuations that businessmen do not care to incur." Ogden (1987) further notes that cash payment streams concentrate payments around the turn of the month, with the largest concentration at the turn of the year. We investigate whether year-end and quarter-end preferences for liquidity are strong enough to cause economically significant changes in interest rates in pound sterling and euro general collateral repurchase agreements.

Griffiths and Winters (1997) find a year-end preferred habitat for liquidity in the term structure of US general collateral government repo rates across one-week, two-week, three-week, and one-month terms. Elsewhere in the money markets, Griffiths and Winters (2005) find a yearend preferred habitat in the US money market one-month maturities for commercial paper, banker's acceptances, negotiable certificates of deposit, euro-dollar deposits, and US dollar LIBOR, while Downing and Oliner (2007) find an increase in the year-end term premia in the term structure of US commercial paper rates. Kotomin et al. (2008) extend Griffiths and Winters (2005) and find the same year-end preferred habitat in LIBOR in the major world currencies-yen, euro, 
German mark, and Swiss franc - in addition to the US dollar, but do not find strong evidence of a preferred habitat in pound sterling. With year-end preferred habitats common throughout the money markets of most of the world's major economies and across the various types of money market instruments, we revisit British interest rates to determine if the lack of a year-end preferred habitat is robust or specific to pound sterling LIBOR. For comparison purposes, we also analyze the behavior of the euro repo (Eurepo) rate - the rate at which one prime European bank offers funds to another in exchange for receiving Eurepo General Collateral instruments as collateral. ${ }^{1}$

We examine the short end of the term structure for euro and pound sterling repo rates for year-end and quarter-end preferred habitats and find strong evidence of a year-end preferred habitat in one-week, two-week, three-week, and one-month Eurepo yields. The quarter-ends in Eurepo rates are suggestive of preferred habitats, but the rate changes are not economically significant. Our results on pound sterling repo rates do not support year-end or quarter-end preferred habitats as customarily defined. However, additional testing indicates that the effective UK business year-end may actually be prior to Christmas and the calendar year-end. Some modest evidence suggests that some rate pressures exist during the last few business days before Christmas. However, upticks in British repo rates do not persist long enough to support the hypothesis of a preferred habitat for liquidity, and they are more indicative of investors entering the market to take advantage of the higher rates. Hence, unlike in the US payment system, the generally reduced concentration of year-end cash obligations in the British payment system permits the existence of increased interest rate arbitrage. Our results are consistent with findings

\footnotetext{
${ }^{1}$ The Eurepo is sponsored by the European Banking Federation, with the support of the European Repo Council, and completes the range of existing benchmark indices, such as Euribor, Eonia, and the Eonia Swap Index.
} 
of previous research and continue to suggest that the behavior of British money market rates at year-ends and quarter-ends is structurally different from other major economies.

\section{Explanations for Calendar Timing Effects and Testable Implications}

Tax-loss selling and window dressing are routinely offered as explanations for the turn-ofthe-year effect in equities. Tax-loss selling does not apply to money market instruments because, absent default, money market instruments always provide taxable gains. Musto (1997) offers flight-from-risk window dressing as an explanation for the higher US commercial paper rates observed at the year-end. Because window dressing is based on disclosure requirements, any effect caused by window dressing must span disclosure dates. Griffiths and Winters $(1997,2005)$ show that the higher year-end rates in the US money market do not persist across the year-end disclosure date and offer year-end preferred habitats for liquidity to explain the observed rate pattern.

A preferred habitat for liquidity is based on investor preferences for instruments that mature before cash obligation dates, so the funds are available to the investor to cover known cash obligations. Ogden (1987) asserts that large amounts of known cash obligations cluster around the year-end, and Griffiths and Winters (2005) note that these obligations need not align with the last business day of the year. Thus, investors (lenders) with year-end preferences for liquidity withdraw from the money markets when the instruments' maturity spans their cash obligation dates, thus resulting in higher rates. Later, investors return to the instruments they exited previously, driving rates back down to normal, with the rate decline beginning before the year-end disclosure date.

For year-end interest rate regularities to support a preferred habitat, rates must increase when the instrument begins spanning year-end cash obligation dates, remain high through the cash obligation dates, and return to normal after the cash obligation dates pass. To differentiate a year- 
end preferred habitat from year-end window dressing, some cash obligation dates must occur before the last business day of the year, allowing rates to begin returning to normal before the yearend. Quarter-ends are also known to have concentrations of cash obligations and reporting disclosures, so the year-end explanations may also apply to quarter-ends (see, for example, Garbade, 1996, chapter 9).

We examine the term structure of repo rates in euros and pound sterling for one-week, twoweek, three-week, and one-month terms. A one-week instrument usually covers five business days, so we expect rates to increase before business day -5 relative to the year-end, remain high for about five business days, and then begin to return to normal prior to the last business day of the yearend. A two-week instrument covers 10 business days, so the rate increase should occur before business day -10 , remain high, and then begin returning to normal prior to the last business day of the year-end. A three-week instrument covering 15 business days would increase before business day -15. Similarly, a one-month instrument spans about 20 business days, so we expect one-month rates to follow the same pattern as one-week, two-week, and three-week rates, but with the rate increase occurring before trading day -20 relative to the year-end. ${ }^{2}$

\title{
3. Data and Methods
}

\author{
3.1 Data
}

\footnotetext{
${ }^{2}$ Due to the observance of Christmas and Boxing Day holidays, an instrument of a particular maturity may cover fewer business days prior to the end of the year.
} 
The primary data are daily repurchase agreement (repo) rates for the pound sterling (GBP) and the euro (EUR). Repos are collateralized lending transactions. One party agrees to sell securities to the other party against a transfer of funds. At the same time, the parties agree to repurchase the same or equivalent securities at a specific price in the future. A seller of securities is a borrower of cash and a buyer is a lender, so the difference between the repurchasing and selling prices represents interest. The securities sold serve as collateral in a repo transaction.

We collect daily GBP repo rates from the British Bankers' Association (BBA) Web site and daily EUR repo (Eurepo) rates partly from the BBA Web site and partly from www.eurepo.org. ${ }^{3}$ Both rates are based upon the concept of general collateral, which allows using any securities acceptable to the cash lender. These are usually generically defined in the repo agreement signed between the counterparties. For GBP repos, this may include any G-7 government bonds or any UK gilts. For Eurepo, general collateral generally refers to any government-guaranteed bills or bonds. ${ }^{4}$

These data are available for maturities of one day (overnight), one week, two weeks, three weeks, one month, two months, and three months, starting May 17, 1999, for both currencies, and for maturities of six, nine, and twelve months, starting December 7, 1999, for GBP and December 8,1999 , for EUR. We focus on the shortest end of the maturity spectrum, in particular, maturities of one month or less, similar to Griffiths and Winters (1997) earlier study on US repo rates. ${ }^{5}$

\footnotetext{
${ }^{3}$ Since the introduction of the Euro, the European repo markets have developed significantly, with more and more emphasis on cross-border financing trades. This has led to an increasingly homogenous Euro-denominated general collateral (GC) market.

${ }^{4}$ There are also "special" repo transactions, which are based on a specific security, that may be highly sought after in the market, perhaps because it is the cheapest-to-deliver security to deliver into a maturing futures contract. Because the primary purpose of special repos is to borrow a particular security rather than to lend cash, special repo rates tend to be lower than general collateral repo rates.

${ }^{5}$ One-day (overnight) rates are quite volatile and do not demonstrate any consistent patterns.
} 
We also collect from Global Financial Data (www.globalfinancialdata.com) the equivalent of a three-month US Treasury bill (T-bill) rate to use as controls for the general level of short-term interest rates. For British rates, we collect the three-month UK gilt; and for euro rates, Global Financial Data provides the three-month German government instrument. The rates on the threemonth German government instrument are available only from October 2000. In the case of GBP, gilt rates are abnormally high and volatile between August 2007 and the end of the sample in February $2008 .{ }^{6}$ Since these T-bill equivalent yields are used as an independent variable in our model, our sample periods are limited to October 2000 through February 2008 for EUR and May 1999 through July 2007 for GBP. These include 1872 daily observations (21 quarter-ends, eight year-ends) for EUR and 2071 daily observations (25 quarter-ends, eight year-ends) for GBP. ${ }^{7}$ Table 1 contains descriptive statistics for the data series utilized in this study. ${ }^{8}$

[Table 1 here]

Panel A of Table 1 provides summary statistics across the sample. We see two interesting features of the data. First, the term premia in both the pound sterling and euro repo rates are very small, when they exist at all. Second, Eurepo rates exceed the German three-month T-bill equivalent rates, while British repo rates are less than the three-month British equivalent. The inversion of the British rates is our first evidence that British money market rates may behave differently from other money market rates.

Panel B of Table 1 provides summary statistics for the month of December where the term premia remain very small and the relation between the repo rates and the T-bill equivalent yields

\footnotetext{
${ }^{6}$ The spike in UK gilt rates approximately coincides with a failure of Northern Rock, a large commercial bank.

${ }^{7}$ We refer hereafter to the ends of calendar quarters one, two, and three as quarter-ends and to the end of the fourth quarter as the year-end.

${ }^{8}$ While we do not use the one-day rate in our main tests due to high volatility, we report descriptive statistics for this series to establish the reference point for other maturities.
} 
maintain the same sign as in the overall sample. However, there are two important differences between the December summary statistics and the sample summary statistics. First, the Eurepo spreads over the German T-bill equivalent increase substantially, suggestive of the year-end rate pressures previously observed in other money markets. However, a similar increase does not occur in the British rates, consistent with the previous findings on pound sterling LIBOR in Kotomin et al. (2008). Second, the British overnight rate deviates substantially from the sample average and the term rates in December.

Panel C of Table 1 provides summary statistics for the calendar quarter-ends (March, June, and September). The summary statistics for these months are similar to the summary statistics from the overall sample suggesting the lack of quarter-end preferred habitats. We expect that, if quarter-end preferred habitats exist, the magnitude would be smaller than any year-end effect. Even though we do not see a quarter-end effect in the summary statistics, in the interest of completeness, we continue to test for this effect.

\subsection{Methods}

As discussed, the interest rate regularity for a preferred habitat for liquidity is characterized by a rate increase when an instrument's maturity spans cash obligation dates, rates remaining abnormally high across the cash obligation dates, and rates declining back to normal after cash obligation dates pass. Accordingly, we need methods that capture the rate changes and the sustained period of abnormally high rates. Griffiths and Winters (1997, 2005) provide the appropriate methods. Accordingly, we begin with the Griffiths and Winters regression model designed to capture the rate changes. Kotomin et al. (2008) introduce calendar quarter-ends into 
the Griffiths and Winters regression model, and we follow their lead. The model is estimated using OLS with White's (1980) adjustment for heteroskedasticity: ${ }^{9}$

$$
\begin{aligned}
& \Delta \mathrm{R}_{\mathrm{t}}=\alpha_{0}+\alpha_{1}\left(\Delta 3 \mathrm{M}_{\mathrm{t}}\right)+\alpha_{2} \mathrm{BYCR}+\alpha_{3} \mathrm{AYCR}+\alpha_{4} \mathrm{BYEND}+\alpha_{5} \mathrm{AYEND}+\alpha_{6} \mathrm{BQCR}+ \\
& \alpha_{7} \mathrm{AQCR}+\alpha_{8} \mathrm{BQEND}+\alpha_{9} \mathrm{AQEND}+\varepsilon_{\mathrm{t}}
\end{aligned}
$$

where

$\Delta \mathrm{R}_{\mathrm{t}} \quad=$ the first difference in the one-week, two-week, three-week, or one-month repo rate for a given currency, in percent;

$\Delta 3 \mathrm{M}_{\mathrm{t}} \quad=$ the first difference in the three-month benchmark rate for the same currency as the dependent variable, in percent;

BYCR = a dummy variable that equals 1 on the two trading days before the maturity of the loan starts to span the end of the year and 0 otherwise; this dummy falls on different days for different maturities;

AYCR = a dummy variable that equals 1 on the two trading days after the maturity of the loan starts to span the end of the year and 0 otherwise; this dummy falls on different days for different maturities;

BYEND = a dummy variable that equals 1 on the last two trading days of the year and 0 otherwise;

AYEND = a dummy variable that equals 1 on the first two trading days of the year and 0 otherwise;

BQCR, AQCR, BQEND, and AQEND are the turn-of-the-quarter dummy variables for the turns of the first three quarters of the year defined similarly to the turn-of-the-year dummies described above.

Specifying the dependent variable as a first difference in rates allows the regression coefficients to be interpreted as daily changes in the repo rate in percentage points. The threemonth treasury equivalent rate has been chosen as the benchmark rate to control for the general

\footnotetext{
${ }^{9}$ We estimate equation (1) separately for GBP and EUR, which implies that the error terms are orthogonal. We believe this is a reasonable assumption because interest rates in each currency are determined by the supply and demand for that currency, and then interest rate parity operates through adjustments in exchange rates.
} 
level of interest rates for a given currency. We recognize the maturity mismatch between the rate being studied and the base rate. However, previous work (for example, Musto, 1997; Griffiths and Winters, 2005; and Kotomin et al., 2008) consistently finds no significant calendar-time effects in three-month rates. Thus, the choice of the three-month benchmark rate minimizes the maturity mismatch while providing a base rate that is not significantly influenced by the forces we examine.

The dummy variables are the test variables for preferred habitats and window dressing, and the parameter estimates are expected to have the following signs under each hypothesis:

\begin{tabular}{|l|c|c|}
\hline $\begin{array}{l}\text { Dummy } \\
\text { variable }\end{array}$ & $\begin{array}{c}\text { Preferred } \\
\text { habitat }\end{array}$ & $\begin{array}{c}\text { Window } \\
\text { dressing }\end{array}$ \\
\hline BYCR & $>0$ & $=0$ \\
\hline AYCR & $=>0$ & $>0$ \\
\hline BYEND & $<0$ & $=0$ \\
\hline AYEND & $<=0$ & $<0$ \\
\hline BQCR & $>0$ & $=0$ \\
\hline AQCR & $=>0$ & $>0$ \\
\hline BQEND & $<0$ & $=0$ \\
\hline AQEND & $<=0$ & $<0$ \\
\hline
\end{tabular}

Clearly, the rate patterns are similar under both hypotheses, but rates move earlier under the preferred habitat hypothesis than under the window dressing hypothesis. That is, the expectations of non-zero parameter estimates occur earlier in calendar time under the preferred habitat hypothesis than under the window dressing hypothesis. This is due to differences in investors' motivation under the two hypotheses. Under the preferred habitat for liquidity hypothesis, investors start reentering money markets after their cash obligations are paid, which may happen prior to the calendar year-end (quarter-end). Under the window dressing hypothesis, investors (especially financial institutions) stay away from short-term private-issue securities or loans until the year-end (quarter-end) disclosure date passes, and this date is aligned with the last business day of the year (quarter) both in the UK and the euro zone. 
The regressions capture the rate changes, but not the period of abnormally high rates between the periods of rate changes. To test for the persistence of abnormally high rates, we employ excess spreads calculated in a manner similar to Griffiths and Winters $(1997,2005)$ :

- First, spreads between repo rates and three-month equivalent rates are calculated for each day in the sample.

- Second, the average spreads are computed for each day in the "event window" for each maturity. The event windows cover trading days -10 through +5 relative to the year- or quarter-end for the one-week maturity, days -15 through +5 for the two-week maturity, days -20 through +5 for the three-week maturity, and days 25 through +5 for the one-month maturity. For example, the spreads across all trading days -3 relative to the end of the year in the sample period are used to calculate the average spread for day -3 .

- Third, a control average is calculated from the spreads on all trading days outside the year-end and quarter-end windows covered in the previous step.

- Finally, the control average is subtracted from the trading day average for each day in the event window to arrive at the excess spreads for individual trading days in the event window.

We plot the excess spreads when presenting these results and discuss the results in terms of economic significance.

\section{Empirical Results}


Regression results and excess spread plots constitute our primary analysis for year-end and quarter-end effects. We begin our discussion with the regression results, which test to determine if significant rate changes occur at specific calendar points. We follow the regression results with a discussion of excess spread plots, which are used to determine if spreads remain abnormally high between the points of significant rate changes. We conclude the results section with a discussion of the British payment system and its potential impact on preferred habitats for liquidity.

\subsection{Regression Results}

We estimate equation (1) separately for each term from one-week through one-month on pound sterling repos and Eurepos. The results are reported in Table 2. Because the dependent variable is specified as a daily change and each dummy variable covers two consecutive days at a time, the dummy variable coefficients should be interpreted as changes in the repo rates in percentage points on each of the two days covered by the dummy.

[Table 2 here]

The Eurepo rates show a consistent year-end effect, with significant and positive parameter estimates on BYCR across all terms followed by significant and negative parameter estimates on BYEND across all terms consistent with a year-end preferred habitat for liquidity and with the Griffiths and Winters (1997) findings on US term repos. In addition, there is support for quarterend preferred habitats in one-week term repos, but not in longer terms. This latter result is consistent with the quarter-end results in Kotomin et al. (2008), who find more support for a quarter-end preferred habitat in one-week LIBOR than in one-month LIBOR.

The pound sterling repo rates also display modest evidence of a year-end preferred habitat for liquidity. That is, the parameter estimates for BYCR are positive (although, only the three- 
week and one-month parameters are statistically significant), ${ }^{10}$ and the parameter estimates on BYEND are significant and negative. There is no evidence in the pound sterling results to suggest a quarter-end effect. The year-end GBP repo results here are not consistent with the finding in British LIBOR from Kotomin et al. (2008). However, we have yet to determine if spreads are abnormally high between the periods of rate changes, which are needed to support a year-end preferred habitat for liquidity. We also discuss these results in greater depth in Section 4.3, where we provide a possible explanation for the differing GBP results.

We note that the results in both currencies are not consistent with the window dressing hypothesis. For the rate changes to be consistent with year-end (quarter-end) window dressing, a positive parameter estimate for the variable AYCR (AQCR) must be accompanied by a negative parameter estimate for the variable AYEND (AQEND). This regularity of rate changes is not found in any maturity in either currency.

\subsection{Excess Spread Plots}

Figures 1 through 4 provide plots of excess spreads. Figures 1 and 2 provide year-end plots, while Figures 3 and 4 provide quarter-ends plots. The $\mathrm{x}$-axis of each plot records trading days relative to the calendar break point. Day -1 is the last trading of a year (quarter), and day +1 is the first trading day of a year (quarter). There is not a day 0 . Using trading days means that each instrument covers fewer days on the plot than days in its term (for example, a one-week repo typically covers five trading days). The y-axis of each plot is excess spread, as defined in Section 3.2. Thus, a zero excess spread means that the average spread on a trading day in a calendar event window equals the average spread on all days not in the calendar event window.

\footnotetext{
${ }^{10}$ We note that, while the one-week and two-week parameter estimates are not statistically significant, the magnitude (in basis points) of these parameter estimates is similar to the magnitude of the statistically significant parameter estimates on the three-week and one-month rates.
} 
Figure 1 provides year-end excess spread plots for Eurepos' one-week, two-week, threeweek, and one-month terms. Each plot exhibits excess spreads consistent with a year-end preferred habitat for liquidity. That is, spreads increase when each term begins to span year-end dates, remain abnormally high across the length of the term, and begin returning to normal levels before the last trading day of the year. ${ }^{11}$ Stigum (1990) notes that money market traders consider 10 to 20 basis points of abnormal spread an attractive opportunity. The one-week excess spreads reach 16 basis points and the two-week excess spreads reach 10 basis points and thus are clearly economically significant. The three-week excess spreads reach a maximum of about 7 basis points and the onemonth excess spread reach a maximum of about 5 basis points, which do not clear Stigum's hurdles. However, Brown et al. (2008) note that the average term premia in the 1980s (when Stigum researched her book) were about 4.5 basis points between overnight and one-month US repo rates. We note that the term premia in our sample is about 0 basis points. In this interest rate environment, an average of 5 to 7 basis points of excess spread may well represent an economically attractive opportunity.

[Figure 1 here]

Figure 2 provides year-end excess spread plots for GBP repos at terms of one week, two weeks, three weeks, and one month. ${ }^{12}$ For each term, excess spreads increase and decrease at times consistent with a preferred habitat for liquidity and consistent with our regression results.

\footnotetext{
${ }^{11}$ We report average excess spreads and suggest that the average fits the pattern for a year-end preferred habitat. However, with only eight year-ends, there can be questions about "average" results, so we have examined the patterns for each year. We find that our averages are not driven be a single outlier year-end. Additionally, for each term, more than half the year-ends have a pattern similar to the pattern reported in Figure 1, with the reminder having relatively flat excess spread patterns. None of the individual year excess-spread plots show a decline in excess spreads during the analysis window. None of the year-end patterns is consistent with flight-from-risk window dressing.

${ }^{12}$ As indicated in footnote 11, we report average excess spreads and suggest that, in the case of GBP, no affirming statement can be made about a year-end preferred habitat. We examined the patterns for each of the eight years in the sample and find that our averages are not driven be a single outlier year-end dragging down the average results. None of the year-end patterns is consistent with flight-from-risk window dressing.
} 
However, to support a preferred habitat at the year-end, excess spreads also need to be abnormally high between the points of increase and decrease. None of the excess spreads in two-week, threeweek, or one-month maturities are abnormally high during the appropriate time period. Instead, excess spreads are generally negative during the time when they need to be abnormally high to support a preferred habitat for liquidity. The one-week term has positive excess spreads at the time needed to support a preferred habitat. However, the excess spreads around the preferred habitat period are also abnormal, which prevents making any affirming statements about a year-end preferred habitat with confidence. The lack of support in the year-end plots for a preferred habitat for liquidity in pound sterling repo rates is consistent with the finding in Kotomin et al. (2008) for pound sterling LIBOR. We discuss this further in the following section.

[Figure 2 here]

Figure 3 provides quarter-end excess spread plots from euro repo rates. The quarter-end excess spreads in the one-week term are consistent with a preferred habitat for liquidity and with our regression results. The one-week excess spread reaches a maximum of about 4 basis points, which is substantially below the 16 basis point maximum at year-end. We expect less rate pressures at quarter-ends because Ogden (1987) notes that the largest concentration of cash obligations is at the year-end. The other term excess spreads also increase at the same time as the one-week excess spreads. However, these increases do not support a preferred habitat for liquidity. Finding a quarter-end preferred habitat for liquidity in the one-week term, but not the longer terms, is generally consistent with the findings of Kotomin et al. (2008).

[Figure 3 here]

Figure 4 provides quarter-end excess spread plots for pound sterling term repo rates, and there is no discernable regularity at any term in these plots. These results are consistent with the 
lack of quarter-end effects in pound sterling LIBOR found in Kotomin et al. (2008). None of the plots in Figures 1 through 4 suggests that the turn-or-the-year and turn-of-the-quarter spread changes in either currency is consistent with the window dressing hypothesis.

[Figure 4 here]

\subsection{Further Discussion of Pound Sterling Results}

The lack of a year-end preferred habitat for liquidity in pound sterling repo rates is consistent with the previous results on pound sterling LIBOR from Kotomin et al. (2008), who do a variety of data and methods checks and conclude that the lack of a preferred habitat in pound sterling LIBOR is not the result of data errors or methodological problems. They declare their pound sterling results puzzling. In this section, we offer a possible explanation for the puzzling year-end results on pound sterling rates.

Ogden (1987) suggests, and Griffiths and Winters (1997, 2005) concur, that the concentration of year-end cash payments causes the pattern observed in the US money market yields. Kotomin et al. (2008) expect a similar concentration of payments at year-end across major world economies. Using monthly central bank data from the Bank of England, the Bank of Japan, and the European Central Bank, they find some evidence of payment system spikes at year-ends in the major economies outside the US. We revisit the issue of year-end payment concentration in the United Kingdom.

Griffiths and Winters (2005) and Kotomin and Winters (2006) find that customer demand deposits in US banks increase in December in preparation for making payments on year-end cash obligations. Kotomin and Winters (2006) also find that banks increase their cash holdings when customers increase their demand deposits. We conduct a deposit analysis by collecting US and UK monthly demand deposits and analyzing the deposit data for increases in December deposits. 
The data on US demand deposits are collected from the US Federal Reserve H8 report, and we collect monthly demand deposits for all commercial banks in the US (not seasonally adjusted). ${ }^{13}$ The data on UK demand deposits are collected from the Bank of England Statistics archive under the heading of sight deposits. At the present time, there are 120 data series available for sight deposits. We chose to collect three month-end data series (not seasonally adjusted): (1) total sight deposits, (2) resident bank sight deposits, and (3) private sector sight deposits. ${ }^{14}$ For our analysis of the deposit data, we estimate the following regression model using OLS with White's adjustment for heteroscedasticity:

$$
\begin{aligned}
\Delta \text { Deposits }_{t}= & \alpha_{1} J A N+\alpha_{2} F E B+\alpha_{3} \text { March }+\alpha_{4} \text { April }+\alpha_{5} \text { May }+\alpha_{6} \text { June }+\alpha_{7} \text { July }+ \\
& \alpha_{8} A U G+\alpha_{9} S E P T+\alpha_{10} O C T+\alpha_{11} N O V+\alpha_{12} D E C+\beta_{1} \text { Trend }+\varepsilon_{t}
\end{aligned}
$$

where $\Delta$ Deposits $_{\mathrm{t}}=$ first difference in monthly deposits,

JAN $\quad=0 / 1$ variable that equals 1 in January and 0 otherwise,

FEB $\quad=\quad 0 / 1$ variable that equals 1 in February and 0 otherwise,

March $\quad=0 / 1$ variable that equals 1 in March and 0 otherwise,

April $\quad=\quad 0 / 1$ variable that equals 1 in April and 0 otherwise,

May $\quad=0 / 1$ variable that equals 1 in May and 0 otherwise,

June $\quad=\quad 0 / 1$ variable that equals 1 in June and 0 otherwise,

July $\quad=\quad 0 / 1$ variable that equals 1 in July and 0 otherwise,

AUG $\quad=\quad 0 / 1$ variable that equals 1 in August and 0 otherwise,

SEPT $\quad=0 / 1$ variable that equals 1 in September and 0 otherwise,

OCT $=0 / 1$ variable that equals 1 in October and 0 otherwise,

NOV $\quad=\quad 0 / 1$ variable that equals 1 in November and 0 otherwise,

DEC $\quad=\quad 0 / 1$ variable that equals 1 in December and 0 otherwise, and

Trend $\quad=\quad$ linear trend variable.

The results of estimating the model are reported in Table 3.

[Table 3 here]

\footnotetext{
${ }^{13}$ We note that the Federal Reserve US bank data are typically collected on Wednesdays, so the US monthly data are not necessarily reported for the last day of the year. However, Kotomin and Winters (2006) find that the increase in year-end deposits typically persists into the first week of the new year.

${ }^{14}$ Note that resident bank sight deposits and private sector sight deposits do not sum to total sight deposits. There are other categories of sight deposits in total sight deposits that we chose not to include in our analysis because of a lack of relevance. For example, we do not include public sector sight deposits.
} 
The December results are the main focus of our discussion. The US demand deposits show a significant increase in December followed by a significant decrease in January. This pattern is consistent with a year-end preferred habitat for liquidity and with the results in Griffiths and Winters (2005) and Kotomin and Winters (2006). The UK total sight deposits also demonstrate statistically significant changes in December and January. However, counter to US demand deposits, UK sight deposits decrease in December and increase in January.

Kotomin and Winters (2006) find that banks increase their cash holding when their depositors increase their demand deposits at the year-end. They conclude that banks are holding cash to accommodate their demand depositors' year-end liquidity needs. Accordingly, we examine sight deposits of UK resident banks to determine if UK banks hold more ready cash at the yearend. The third column of Table 3 reports the regression results for UK bank sight deposits, and we find no evidence of a calendar year-end effect. This suggests that UK banks do not increase their own sight deposits at the year-end. This result is consistent with our other results suggesting the lack of UK calendar year-end preferred habitat for liquidity.

We conjecture that the UK change in sight deposits results from the actual payment of yearend obligations by UK-based institutions. Recall that such obligations need not be on the last day of the year, but that the sight deposit data are (roughly) year-end data. The decrease in sight deposits in UK banks in December is followed by an increase in January, just as US demand deposits decline in January followed by an increase in February. If the effective year-end in the UK occurs before December 25th, then this is precisely the expectation for month-end demand deposits that would be hypothesized.

Finally, we find that total sight deposits and private sector sight deposits increase significantly in the last month of the first three calendar quarters and decline in the first month of 
the next calendar quarter. This deposit regularity is consistent with the pattern expected under quarter-end preferred habitats. However, none of our previous analyses supports quarter-end preferred habitats for liquidity in the UK. The combination of all of our UK quarter-end results is consistent with a lack of cash obligation concentration at the turn of the quarter in the UK.

Ideally, we would also like to analyze euro-zone demand deposits. However, we are unable to find any time series on demand or sight deposits at the European Central Bank, although we are able to find monthly total deposits. Total deposits include both demand and time deposits, which move in opposite directions under preferred habitats for liquidity, and we have no way of determining whether demand or time deposits will dominate. Nonetheless, we estimate our deposit regression on euro-zone total deposits and find that total deposits do increase in December. ${ }^{15}$ However, total deposits continue to increase in January. Having demand deposits dominate in December, with time deposits dominating in January, would be consistent with our on euro-zone total deposit results.

The deposit results support our earlier results and continue to suggest the UK year-end is different. However, these results do not offer an explanation for why the UK is different. We provide a possible explanation below.

Through a series of inquiries, we identified a contact familiar with the micro-mechanics of the British payment system. From this contact, two details of the British payment system emerged that may explain the lack of a calendar year-end preferred habitat for liquidity in pound sterling interest rates. First, the week between Christmas and New Year is much more of a business holiday in the UK than in the US and other major economies. While we were aware of the Boxing Day holiday on the day after Christmas, we were informed that very little business activity also occurs

\footnotetext{
15 These results are not reported in tabular form for the sake of brevity, but are available upon request.
} 
throughout the remainder of the week. Second, it appears that cash payments are not as concentrated at the end of the month (and therefore not at the end of the year) in the UK. These two insights suggest that any year-end preferred habitat for liquidity in the UK would be both smaller in size and likely to move back from the year-end to the last business week before Christmas.

To explore the possible alternative location of the year-end preferred habitat for liquidity in the UK, we revisit the year-end excess spread plot in Figure 2 and move the last trading day of the year (day -1) to the last business day before Christmas. With this shift in the location of the effective year-end, we also recalculate excess spreads since the days included in the plot and the days used in the control spread change. The new year-end plot for pound sterling excess spreads appears as Figure 5.

[Figure 5 here]

Several important insights emerge from Figure 5. First, the pattern in one-week excess spread is now consistent with a year-end preferred habitat for liquidity that covers trading days-10 through -5 relative to Christmas (approximately the period between December 10 and December 17). Both the increase and decrease of excess spreads in this pattern are statistically significant at the 5\% level. This regularity was not apparent in Figure 2 because the one-week excess spread plot did not extend this far back from the last trading day of the calendar year. This modified regularity is consistent with short-term planning for cash obligations in the last two weeks before Christmas. Second, as we move back in time five days from trading day -10, we observe an uptick in the excess spread on the two-week repo. Another five days back reveals an uptick in the three-week excess spread, and five days earlier uncovers an uptick in the one-month spread. These upticks indicate some rate pressures aligned with the last few business days before 
Christmas. However, the upticks are neither statistically nor economically significant, and they do not persist long enough to support a preferred habitat for liquidity. Instead, these results suggest that investors (lenders) enter the market to take advantage of the higher rates driving the rates back down. This is consistent with a lower concentration of cash obligations in the British payment system than in the US payment system.

As a robustness check on our results, we also examined the number of countries and city states that employ the euro as their currency and which observe December 26 (Boxing Day in the UK, St. Stephen's Day or the second day of Christmas in several European countries) and found there are 20 such entities. ${ }^{16}$ We then determined the amount of 2007 GDP (translated into US dollars, as reported in the World Factbook available from www.cia.gov) for those countries to determine an estimate of the proportion of the countries' economies that were subject to the additional holiday at the calendar year-end. We find that $76.6 \%$ of the total euro-based GDP is produced in countries observing the second day of Christmas as a statutory holiday. ${ }^{17}$ Hence, at the margin, a significant portion (23.4\%) of the euro-based GDP does not experience the shortened work week that occurs in the UK at the calendar year-end and is therefore a more "regular" business week and, thus, provides adequate opportunity for a preferred habitat for cash to occur at this time.

In summary, we offer a two-part explanation for why year-end spread patterns in British interest rates differ from the regularity observed across the other major world economies; namely, that the effective business year-end in Britain is the day before Christmas and that cash payments

\footnotetext{
16 The 20 countries and city states are Andorra, Austria (O), Belgium (O), Cyprus, Finland (O), France, Germany (O), Greece (O), Ireland (O), Italy (O), Luxembourg, Malta, Monaco, Montenegro, Netherlands (O), Portugal, San Marino (O), Spain (O) and Vatican City (O). (O) indicates observation of a statutory holiday on December 26.

${ }^{17}$ Vatican City was omitted from this calculation since GDP is a meaningless concept for this city state.
} 
are less concentrated at the calendar year-end in Britain than in the other major world economies. The plots presented in Figure 5 and the results reported in Table 3 are consistent with this two-part explanation.

\section{Conclusion}

Previous research finds support for a year-end preferred habitat for liquidity in the US money markets for terms from one-week through one-month. Kotomin et al. (2008) find similar results in LIBOR in major world currencies, with the exception of the pound sterling. Using GBP repo and Eurepo rates for one-week through one-month terms, we examine the robustness of the Kotomin et al. results.

We find strong support for a year-end preferred habitat for liquidity across all terms in Eurepo rates and only limited support for a year-end preferred habitat for liquidity in the pound sterling repo rates. None of the interest rate changes is consistent with the potential competing hypothesis: window dressing by financial institutions. We offer a two-part explanation for the different results in the GBP repo rates. The explanation suggests that the British payment system is less concentrated than the payment systems of the other major world economies and that the effective business year-end in Britain is the day before Christmas. This explanation is supported by month-end UK bank data, which demonstrate a similar change in demand deposits as in the US after adjusting for the change in the effective year-end. That is, we present preliminary evidence of a structural difference between the British cash payment system and that of most other major economies. 


\section{References}

Brown, C., Cyree, K., Griffiths, M., Winters, D., 2008. Further analysis of the expectations hypothesis using very short-term rates, Journal of Banking and Finance 32, 600-613.

Downing, C., Oliner, S., 2007. The term structure of commercial paper rates, Journal of Financial Economics, 83, 59-86.

Garbade, K.D., 1996. Fixed Income Analytics. MIT Press: Cambridge, Mass.

Griffiths, M., Winters, D., 1997. On a preferred habitat for liquidity at the turn-of-the-year: Evidence from the term-repo market, Journal of Financial Services Research 12, 21-38.

Griffiths, M., Winters, D., 2005. The-turn-of-the-year in money markets: Tests of the risk-shifting window dressing and preferred habitat hypotheses, Journal of Business 78, 1337-1364.

Kotomin, V., D. Winters, 2006. Quarter-end effects in banks: Preferred habitat or window dressing, Journal of Financial Services Research, 29, 61-82.

Kotomin, V., Smith, S., Winters, D., 2008. Preferred habitat for liquidity in international shortterm interest rates, Journal of Banking and Finance 32, 240-250.

Modigliani, F., Sutch, R., 1966. Innovations in interest rate policy, American Economic Review, $56,178-197$. 
Musto, D., 1997. Portfolio disclosures and year-end price shifts, Journal of Finance, 52, 18611882.

Ogden, J., 1987. The end of the month as a preferred habitat: a test of operational efficiency in the money market, Journal of Financial and Quantitative Analysis 22, 329-344.

Roll, R., 1970. The behavior of interest rates: An application of the efficient market model to US Treasury bills. Basic Books: New York.

Stigum, M., 1990. The money market, Third edition. Dow Jones-Irwin: Homewood, Ill.

White, H., 1980. A heteroskedasticity-consistent covariance matrix estimator and a direct test for heteroskedasticity, Econometrica 48, 817-838. 
Table 1. Descriptive statistics.

\begin{tabular}{|c|c|c|c|c|c|c|c|}
\hline \multicolumn{8}{|c|}{ Panel A. Descriptive statistics for the entire sample } \\
\hline & & \multicolumn{3}{|c|}{ Rates, \% } & \multicolumn{3}{|c|}{ Spread over T-bill, basis pts. } \\
\hline & & Mean & Median & St.dev. & Mean & Median & St.dev. \\
\hline \multirow[t]{6}{*}{ Euro } & 1-day & 3.07 & 3.04 & 0.94 & 5.70 & 4.38 & 18.38 \\
\hline & 1-week & 3.06 & 3.04 & 0.93 & 4.87 & 4.00 & 15.04 \\
\hline & 2-week & 3.06 & 3.04 & 0.93 & 4.79 & 4.00 & 13.48 \\
\hline & 3-week & 3.06 & 3.04 & 0.92 & 4.58 & 4.00 & 12.20 \\
\hline & 1-month & 3.06 & 3.05 & 0.92 & 4.39 & 4.00 & 10.78 \\
\hline & T-Bill & 3.01 & 3.02 & 0.89 & & & \\
\hline \multirow{6}{*}{$\begin{array}{l}\text { Pound } \\
\text { Sterling }\end{array}$} & 1-day & 4.68 & 4.69 & 0.81 & -8.36 & -8.83 & 40.73 \\
\hline & 1-week & 4.66 & 4.71 & 0.75 & -9.75 & -7.82 & 20.45 \\
\hline & 2-week & 4.67 & 4.72 & 0.74 & -9.16 & -7.33 & 14.50 \\
\hline & 3-week & 4.67 & 4.72 & 0.73 & -9.33 & -7.33 & 12.04 \\
\hline & 1-month & 4.66 & 4.71 & 0.73 & -9.72 & -7.97 & 10.59 \\
\hline & T-Bill & 4.76 & 4.80 & 0.74 & & & \\
\hline \multicolumn{8}{|c|}{ Panel B. Descriptive statistics for the month of December only } \\
\hline \multirow{2}{*}{\multicolumn{2}{|c|}{ (2) }} & \multicolumn{3}{|c|}{ Rates, $\%$} & \multicolumn{3}{|c|}{ Spread over T-bill, basis pts. } \\
\hline & & Mean & Median & St.dev. & Mean & Median & St.dev. \\
\hline \multirow{6}{*}{ Euro } & 1-day & 3.11 & 3.28 & 0.94 & 6.70 & 5.57 & 18.79 \\
\hline & 1-week & 3.11 & 3.20 & 0.92 & 6.79 & 5.84 & 12.98 \\
\hline & 2-week & 3.12 & 3.07 & 0.92 & 7.69 & 8.00 & 10.31 \\
\hline & 3-week & 3.12 & 3.00 & 0.92 & 7.92 & 7.47 & 8.74 \\
\hline & 1-month & 3.12 & 2.97 & 0.92 & 7.84 & 6.00 & 8.09 \\
\hline & T-Bill & 3.04 & 2.88 & 0.88 & & & \\
\hline \multirow{6}{*}{$\begin{array}{l}\text { Pound } \\
\text { Sterling }\end{array}$} & 1-day & 4.72 & 4.75 & 0.66 & 0.78 & 2.67 & 54.03 \\
\hline & 1-week & 4.64 & 4.59 & 0.66 & -6.86 & 0.50 & 29.69 \\
\hline & 2-week & 4.62 & 4.57 & 0.67 & -9.06 & -3.00 & 18.14 \\
\hline & 3-week & 4.61 & 4.54 & 0.67 & -10.18 & -6.83 & 13.99 \\
\hline & 1-month & 4.60 & 4.52 & 0.67 & -10.97 & -8.67 & 11.70 \\
\hline & T-Bill & 4.71 & 4.53 & 0.70 & & & \\
\hline \multicolumn{8}{|c|}{ Panel C. Descriptive statistics for the months of March, June, and September } \\
\hline \multirow{2}{*}{\multicolumn{2}{|c|}{ 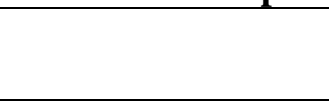 }} & \multicolumn{3}{|c|}{ Rates, $\%$} & \multicolumn{3}{|c|}{ Spread over T-bill, basis pts. } \\
\hline & & Mean & Median & St.dev. & Mean & Median & St.dev. \\
\hline \multirow{6}{*}{ Euro } & 1-day & 2.97 & 2.83 & 0.91 & 4.94 & 4.50 & 18.36 \\
\hline & 1-week & 2.97 & 2.77 & 0.90 & 5.13 & 4.80 & 15.19 \\
\hline & 2-week & 2.97 & 2.71 & 0.90 & 4.99 & 5.00 & 13.08 \\
\hline & 3-week & 2.97 & 2.75 & 0.90 & 4.75 & 4.60 & 11.66 \\
\hline & 1-month & 2.97 & 2.79 & 0.90 & 4.46 & 4.60 & 10.28 \\
\hline & T-Bill & 2.92 & 2.82 & 0.87 & & & \\
\hline \multirow{6}{*}{$\begin{array}{l}\text { Pound } \\
\text { Sterling }\end{array}$} & 1-day & 4.70 & 4.69 & 0.78 & -9.40 & -9.00 & 39.32 \\
\hline & 1-week & 4.69 & 4.73 & 0.73 & -10.36 & -9.83 & 20.84 \\
\hline & 2-week & 4.70 & 4.74 & 0.72 & -9.51 & -8.35 & 15.28 \\
\hline & 3-week & 4.70 & 4.73 & 0.72 & -9.67 & -8.67 & 12.66 \\
\hline & 1-month & 4.69 & 4.73 & 0.72 & -10.04 & -8.35 & 11.06 \\
\hline & T-Bill & 4.79 & 4.80 & 0.73 & & & \\
\hline
\end{tabular}

Descriptive statistics are for daily one-day, one-week, two-week, three-week, and one-month repurchase agreement rates, three-month T-bill yields, and spreads of each repo rate over the T-bill rate for the pound sterling over the period May 19, 1999, through July 31, 2007 (2071 observations), and the euro over the period from October 2, 2000, through February 29, 2008 (1872 observations). 
Table 2. Regression results.

\begin{tabular}{|c|c|c|c|c|c|c|c|c|}
\hline $\begin{array}{l}\text { DV/ } \\
\text { IV }\end{array}$ & $\begin{array}{l}\text { EUR } \\
1 \text {-wk } \\
\end{array}$ & $\begin{array}{l}\text { EUR } \\
2 \text {-wk }\end{array}$ & $\begin{array}{l}\text { EUR } \\
\text { 3-wk }\end{array}$ & $\begin{array}{l}\text { EUR } \\
1-m n \\
\end{array}$ & $\begin{array}{l}\text { GBP } \\
\text { 1-wk }\end{array}$ & $\begin{array}{l}\text { GBP } \\
2-w k\end{array}$ & $\begin{array}{l}\text { GBP } \\
\text { 3-wk }\end{array}$ & $\begin{array}{l}\text { GBP } \\
1-\mathrm{mn}\end{array}$ \\
\hline$\Delta \mathbf{T B}_{\mathrm{t}}$ & $0.245^{* * *}$ & $0.198 * *$ & $0.195 * *$ & $0.196 * *$ & $0.605^{* * *}$ & $0.383 * * *$ & $0.284 * * *$ & $0.248 * * *$ \\
\hline BYCR & $0.035 * * *$ & $0.021 * * *$ & $0.021 * * *$ & $0.017 * * *$ & 0.025 & 0.017 & $0.012 * * *$ & $0.015 * *$ \\
\hline AYCR & -0.041 & -0.002 & $0.009 * * *$ & -0.001 & -0.023 & $-0.019 *$ & -0.024 & -0.006 \\
\hline BYEND & $-0.050 * * *$ & $-0.021 * * *$ & $-0.014 * *$ & $-0.010 * *$ & $-0.062 *$ & $-0.030 * *$ & $-0.015^{*}$ & $-0.008 * *$ \\
\hline AYEND & -0.002 & -0.005 & -0.002 & -0.001 & 0.067 & 0.037 & 0.025 & 0.022 \\
\hline BQCR & $0.014 * * *$ & 0.000 & $0.007 *$ & 0.001 & -0.024 & -0.004 & 0.000 & 0.001 \\
\hline AQCR & $0.006^{* * *}$ & -0.011 & 0.000 & 0.000 & $0.035^{* *}$ & 0.010 & 0.001 & 0.001 \\
\hline BQEND & $-0.017 * * *$ & -0.005 & -0.001 & -0.001 & 0.003 & -0.002 & -0.001 & -0.001 \\
\hline AQEND & -0.002 & -0.002 & -0.001 & -0.001 & 0.017 & $0.012 *$ & $0.008^{*}$ & $0.008 * *$ \\
\hline $\begin{array}{l}\text { F-stat. } \\
\text { Adj. } \text { R }^{2}\end{array}$ & $\begin{array}{l}13.580 * * * \\
0.057\end{array}$ & $\begin{array}{l}16.938 * * * \\
0.071\end{array}$ & $\begin{array}{l}21.227 * * * \\
0.089\end{array}$ & $\begin{array}{l}22.600 * * * \\
0.094\end{array}$ & $\begin{array}{l}6.880 \text { *** } \\
0.025\end{array}$ & $\begin{array}{l}9.673 * * * \\
0.036\end{array}$ & $\begin{array}{l}12.129 * * * \\
0.046\end{array}$ & $\begin{array}{l}16.000^{* * *} \\
0.061\end{array}$ \\
\hline
\end{tabular}

The table reports turn-of-the-year and turn-of-the-quarter effects in repurchase agreement (repo) rates for euro (EUR) and pound sterling (GBP) in the one-week, two-week, three-week, and one-month maturities. The parameters are estimated using the following regression model with the White's adjustment for heteroskedasticity:

$\Delta \mathrm{R}_{\mathrm{t}}=\alpha_{0}+\alpha_{1}\left(\Delta \mathrm{TB}_{\mathrm{t}}\right)+\alpha_{2} \mathrm{BYCR}+\alpha_{3} \mathrm{AYCR}+\alpha_{4} \mathrm{BYEND}+\alpha_{5} \mathrm{AYEND}+\alpha_{6} \mathrm{BQCR}+\alpha_{7} \mathrm{AQCR}+\alpha_{8} \mathrm{BQEND}+$ $\alpha_{9} \mathrm{AQEND}+\varepsilon_{\mathrm{t}}$

The dependent variable is the daily change (in percent) in the repo rate for a given currency and maturity; the independent variables include the change in the three-month T-bill rate for a given currency and dummy variables. Dummies BYCR, AYCR, BYEND, and AYEND are designed to capture interest rate changes around the turn of the calendar year, while BQCR, AQCR, BQEND, and AQEND perform the same function for turns of quarters one, two, and three.

$* * *, * *$, and $*$ denote statistical significance at the $1 \%, 5 \%$, and $10 \%$ level. 
Table 3. Regression results on changes in monthly deposits (billions).

\begin{tabular}{|l|c|c|c|c|}
\hline & $\begin{array}{c}\text { Total } \\
\text { demand } \\
\text { deposits- } \\
\text { US }\end{array}$ & $\begin{array}{c}\text { Total } \\
\text { demand } \\
\text { deposits- } \\
\text { UK }\end{array}$ & $\begin{array}{c}\text { Bank } \\
\text { deposits - } \\
\text { UK }\end{array}$ & $\begin{array}{c}\text { Private } \\
\text { sector } \\
\text { deposits- } \\
\text { UK }\end{array}$ \\
\hline Jan & $-22.5^{* * *}$ & $5.6^{*}$ & 4.0 & $-2.8^{* *}$ \\
\hline Feb & $-20.0^{* * *}$ & -2.0 & 0.9 & 0.6 \\
\hline March & $8.5^{*}$ & $12.8^{* * *}$ & 2.5 & $12.8^{* * *}$ \\
\hline April & 7.1 & $-10.1^{* * *}$ & -0.3 & $-3.8^{* * *}$ \\
\hline May & $-13.7^{* * *}$ & $6.2^{*}$ & 3.7 & $2.8^{* *}$ \\
\hline June & 2.1 & $6.7^{* *}$ & 4.2 & $8.8^{* * *}$ \\
\hline July & $-11.8^{* *}$ & $-9.0^{* * *}$ & 1.5 & $-5.4^{* * *}$ \\
\hline Aug & -3.3 & -3.0 & 4.5 & 2.2 \\
\hline Sept & $8.5^{*}$ & $9.5^{* * *}$ & -4.7 & $8.2 * * *$ \\
\hline Oct & -3.1 & -5.0 & 1.5 & -1.9 \\
\hline Nov & $11.1 * *$ & 3.4 & 3.3 & $4.4 * * *$ \\
\hline Dec & $25.3^{* * *}$ & $-7.2^{* *}$ & -0.9 & -0.6 \\
\hline Trend & 0.01 & $0.07^{* * *}$ & -0.02 & $.02 * * *$ \\
\hline F-stat & $8.88^{* * *}$ & $9.85^{* * *}$ & 0.86 & $26.72 * * *$ \\
\hline Adj. $\mathrm{R}^{2}$ & 0.4503 & 0.4793 & -0.0149 & 0.7279 \\
\hline
\end{tabular}

Resident bank sight deposits and private sector sight deposits do not sum to total sight deposits, as there are other categories of sight deposits in total sight deposits that we do not to include in our analysis due to a lack of relevance.

The parameters are estimated using the following regression model with the White's adjustment for heteroskedasticity:

$$
\begin{aligned}
\Delta \text { Deposits }_{t}= & \alpha_{1} J A N+\alpha_{2} F E B+\alpha_{3} \text { March }+\alpha_{4} \text { April }+\alpha_{5} \text { May }+\alpha_{6} \text { June }+\alpha_{7} \text { July }+ \\
& \alpha_{8} A U G+\alpha_{9} S E P T+\alpha_{10} O C T+\alpha_{11} N O V+\alpha_{12} D E C+\beta_{1} \text { Trend }+\varepsilon_{t}
\end{aligned}
$$

where $\Delta$ Deposits $_{\mathrm{t}}=\quad$ first difference in monthly deposits,

JAN $\quad=\quad 0 / 1$ variable that equals 1 in January and 0 otherwise,

FEB $\quad=\quad 0 / 1$ variable that equals 1 in February and 0 otherwise,

March $\quad=\quad 0 / 1$ variable that equals 1 in March and 0 otherwise,

April $\quad=\quad 0 / 1$ variable that equals 1 in April and 0 otherwise,

May $\quad=\quad 0 / 1$ variable that equals 1 in May and 0 otherwise,

June $\quad=\quad 0 / 1$ variable that equals 1 in June and 0 otherwise,

July $\quad=\quad 0 / 1$ variable that equals 1 in July and 0 otherwise,

AUG $\quad=\quad 0 / 1$ variable that equals 1 in August and 0 otherwise,

SEPT $\quad=\quad 0 / 1$ variable that equals 1 in September and 0 otherwise,

OCT $\quad=\quad 0 / 1$ variable that equals 1 in October and 0 otherwise,

NOV $\quad=\quad 0 / 1$ variable that equals 1 in November and 0 otherwise,

DEC $\quad=\quad 0 / 1$ variable that equals 1 in December and 0 otherwise, and

Trend $\quad=\quad$ linear trend variable.

The model is estimated using OLS with White's adjustment for heteroscedasticity.

$* * *, * *$, and $*$ denote statistical significance at the $1 \%, 5 \%$, and $10 \%$ level. 


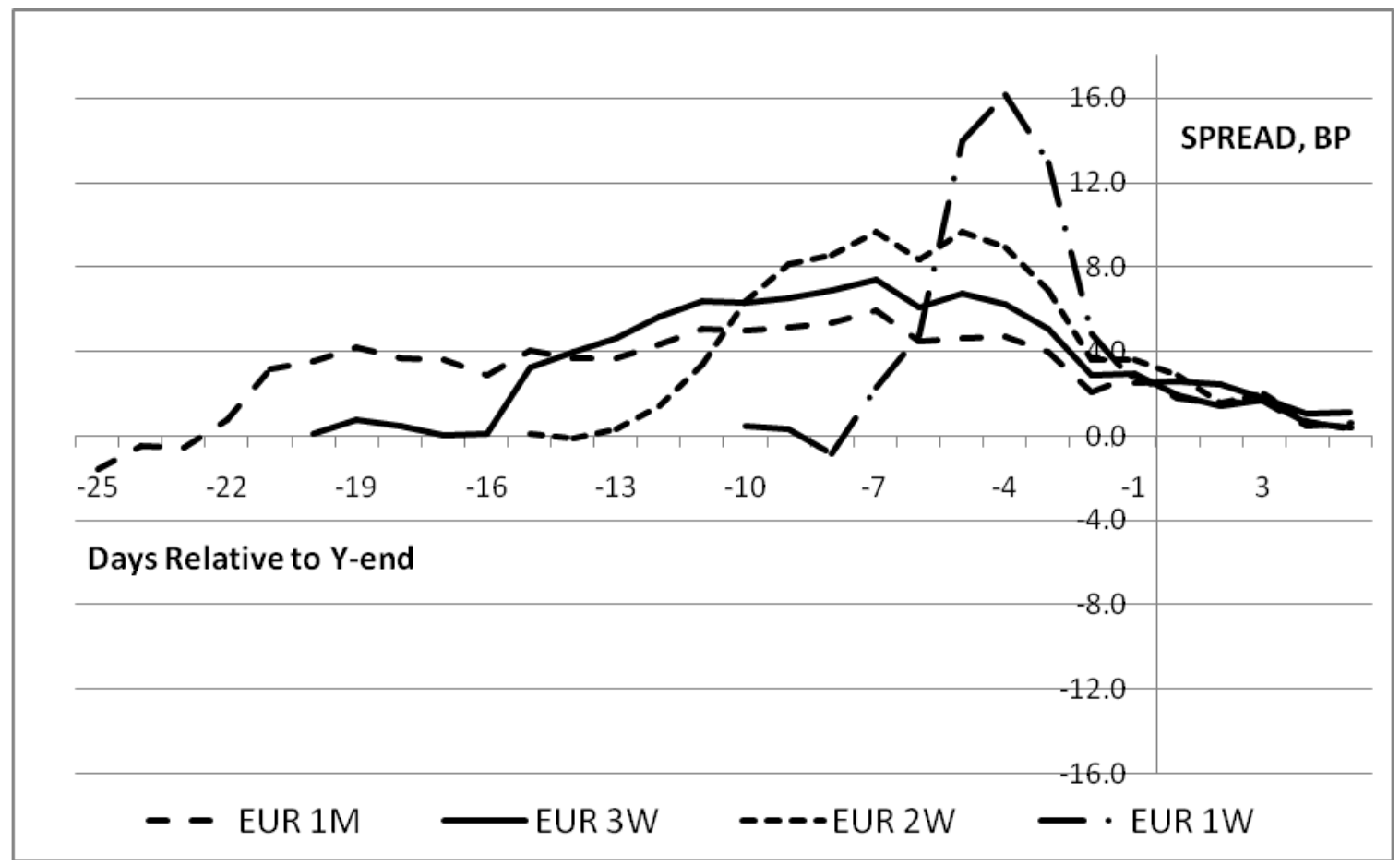

Figure 1. Average excess spreads between one-week, two-week, three-week, and one-month Eurepo rates and three-month Euribor rates for the year-ends (2000 through 2007). 


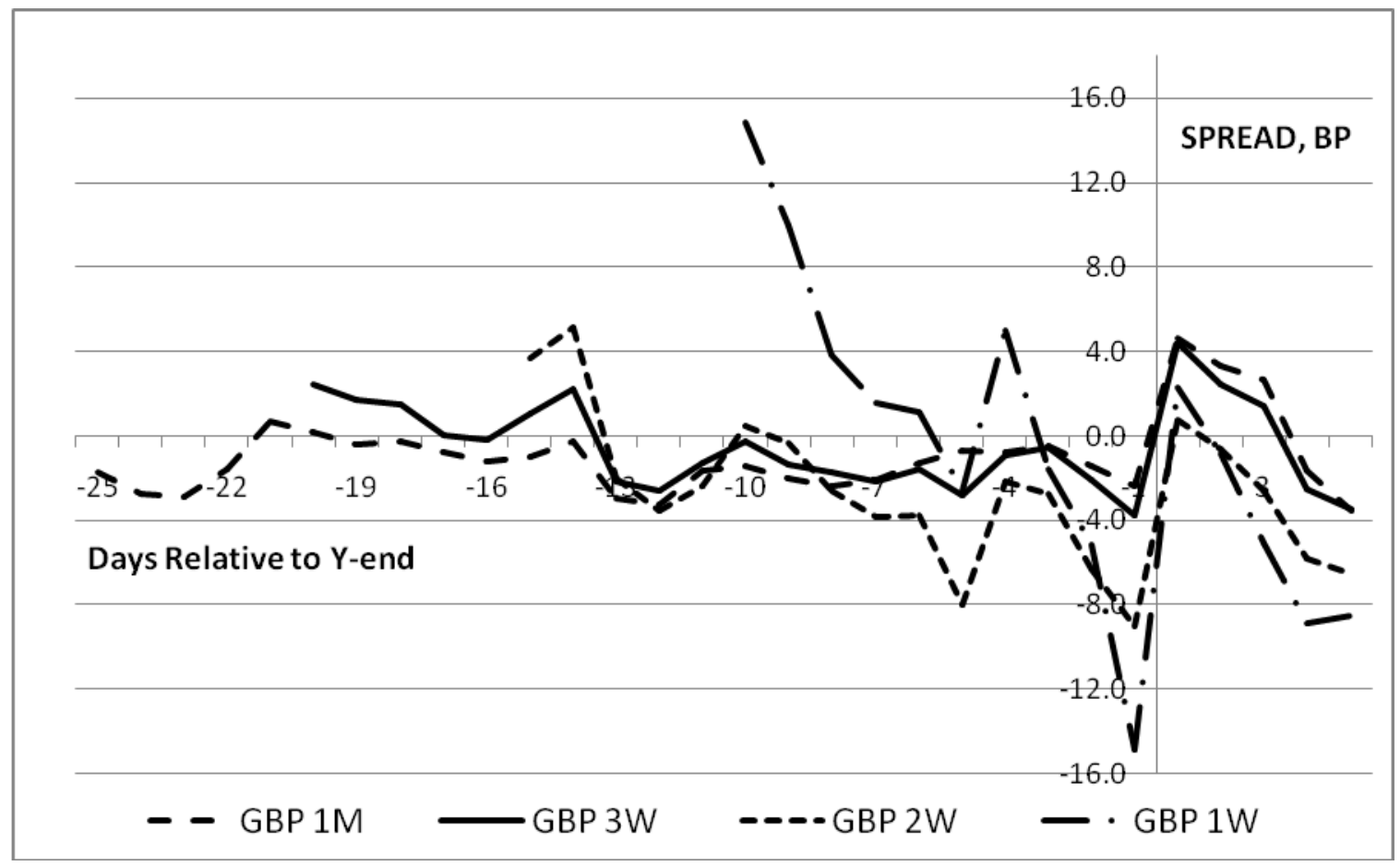

Figure 2. Average excess spreads between one-week, two-week, three-week, and one-month GBP repo rates and three-month GBP gilt rates for the year-ends (1999 through 2006). 


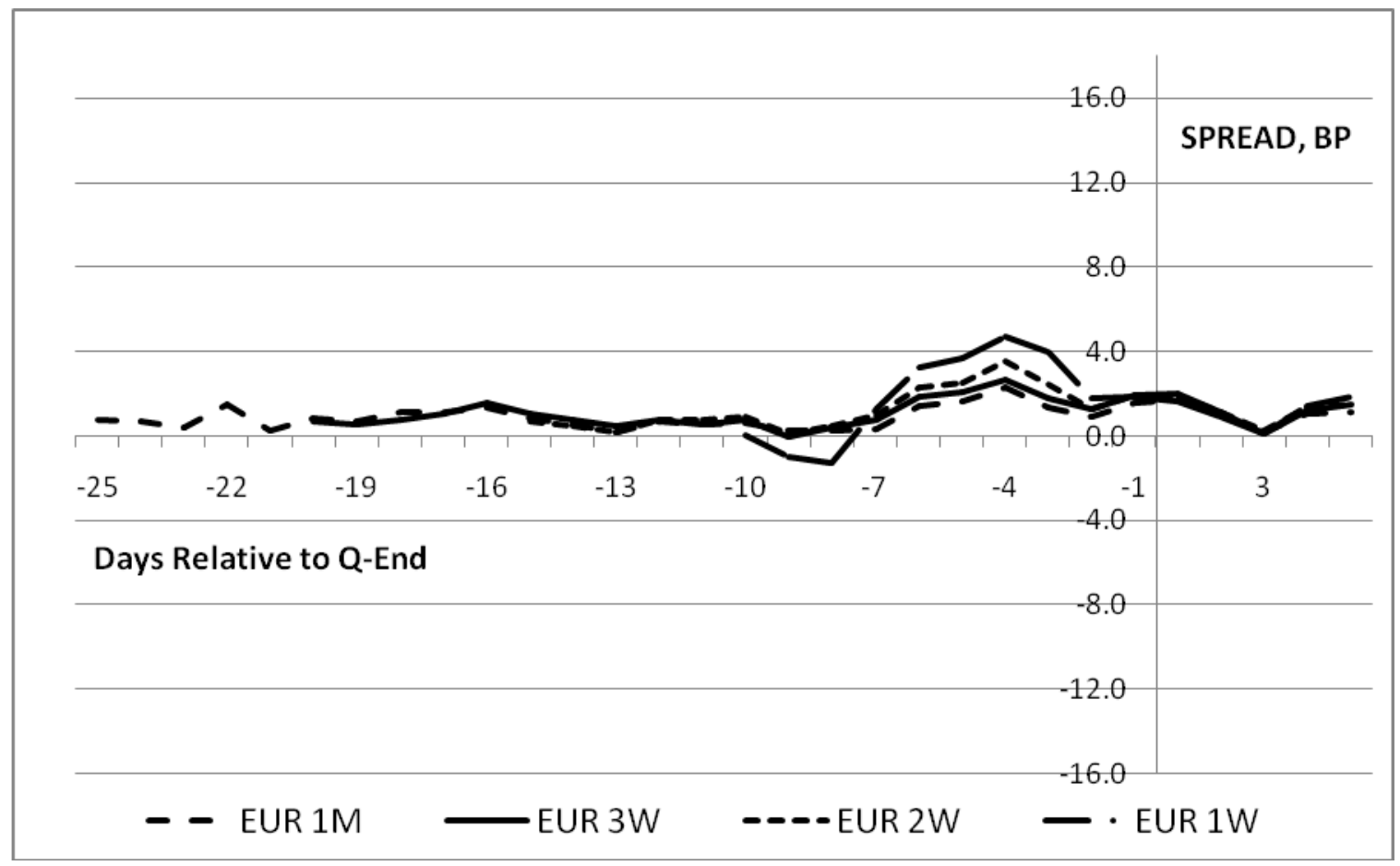

Figure 3. Average excess spreads between one-week, two-week, three-week, and one-month Eurepo rates and three-month Euribor rates around quarter-ends, excluding year-ends (1:01 through 3:07). 


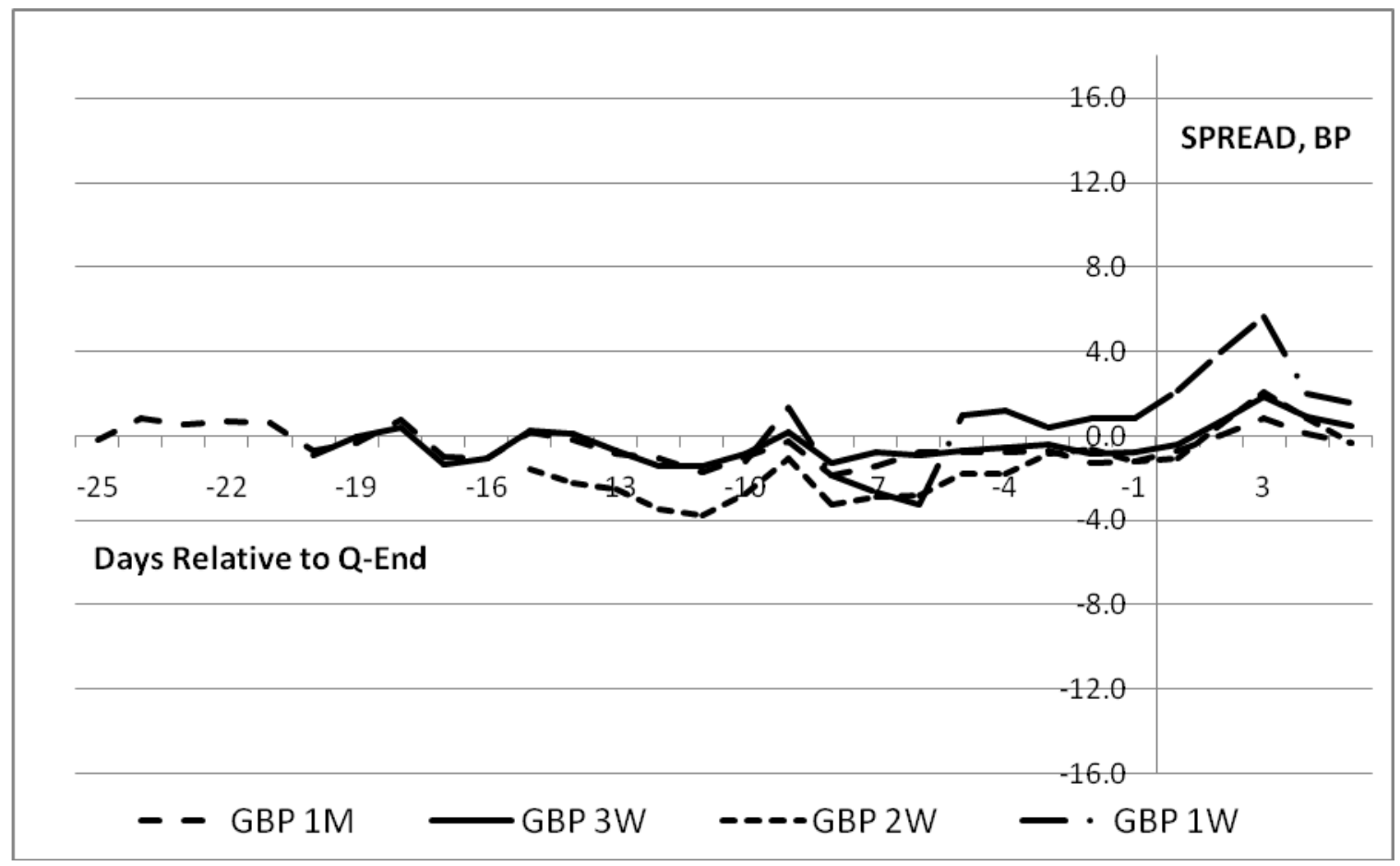

Figure 4. Average excess spreads between one-week, two-week, three-week, and one-month GBP repo rates and three-month GBP gilt rates around quarter-ends, excluding year-ends (2:99 through 2:07). 


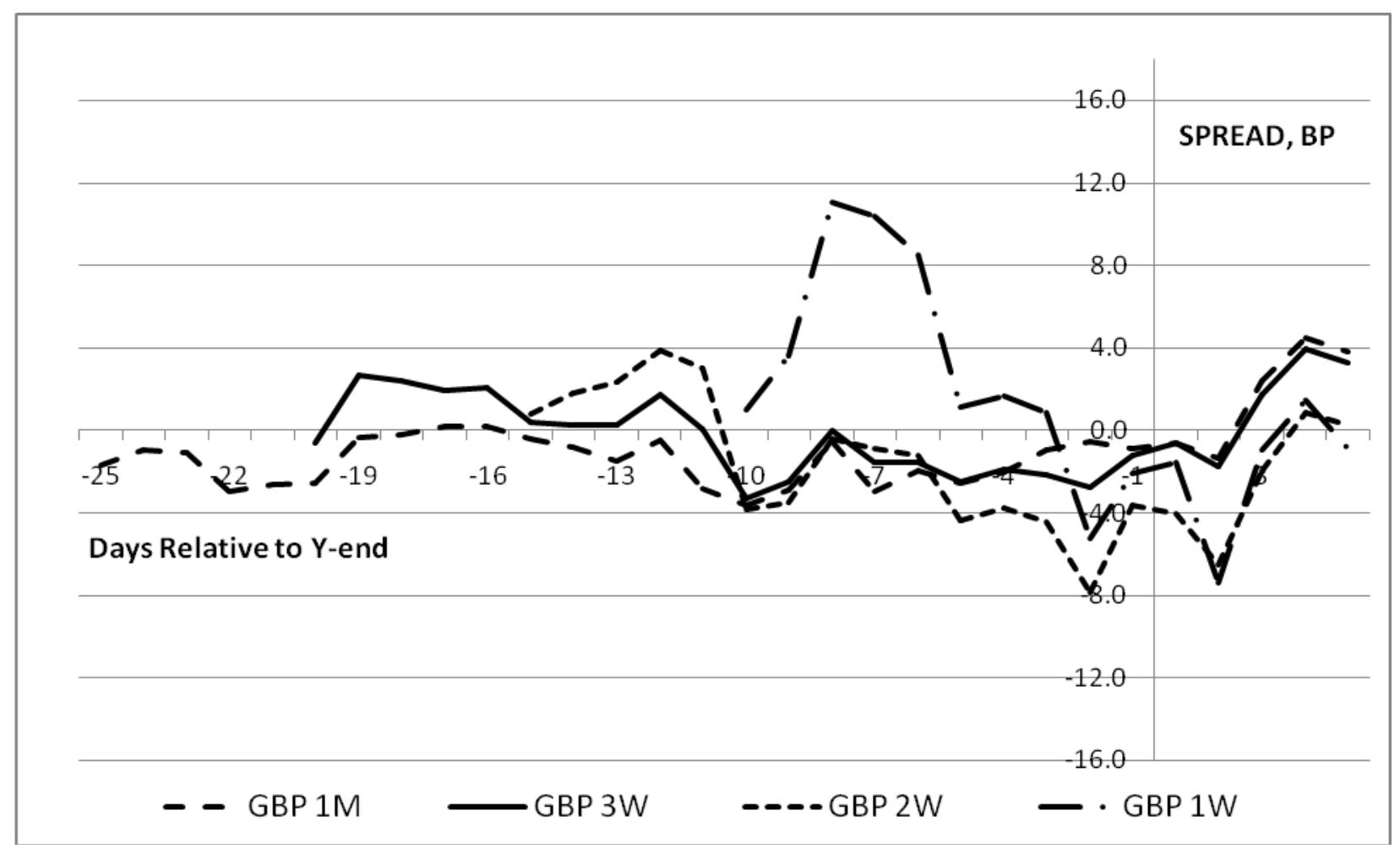

Figure 5. Average excess spreads between one-week, two-week, three-week, and one-month GBP repo rates and three-month GBP gilt rates around year-ends (1999 through 2006) when year-end is adjusted such that $12 / 24$ is day -1 . 